Roy J. Shephard is a member of the Department of Environmental Health, School of Hygiene, University of Toronto.

S. Itoh is a member of the Department of Physiology, Hokkaido University School of Medicine, Japan.

This volume presents in tightly edited form more than ninety papers from the third international symposium on circumpolar health, held in Yellowknife in July 1974.

The conference brought together physicians and paramedical professionals from all the circumpolar nations. They discussed methods of delivering health care and education to isolated communities, the epidemiology and pathology of current epidemics, and the many physiological, social, psychological, and medical problems arising from the sudden acculturation of indigenous northern peoples to a western life-style.

Physiologists and nutritionists will be interested in the effects of changes from natural to processed foods and of diminished levels of physical activity; sociologists and psychologists in adaptations to rapid social change and the attendant problems of alcoholism and violence; epidemiologists in the spread and subsequent control of bacteria, viruses, and parasites previously unknown in northern communities; physicians in such common northern problems as upper respiratory and ear infections; dental surgeons in the impact of changing foods on oral health; and geneticists and anthropologists in the potential for study of small communities of a common basic stock which have lived in isolation for many centuries.

Many of the problems encountered by white workers in the north - exposure to cold, venereal disease, unusual rhythms of light and darkness, responses to isolation, and even relationships between isolated professionals and their university-based supervisors - are also discussed. 

Proceedings of the 3rd International Symposium, Yellowknife, NWT

\section{CIRCUMPOLAR HEALTH}

Edited by

ROY J. SHEPHARD

Department of Environmental Health, School of Hygiene, University of Toronto

S. ITOH

Department of Physiology, University of Hokkaido

Published for Health and Welfare Canada, Medical Services Branch, Northwest Territories Region by University of Toronto Press, Toronto and Buffalo 
(C) University of Toronto Press 1976

Toronto and Buffalo

Printed in Canada

Reprinted in 2018

Library of Congress Cataloging in Publication Data

International Symposium on Circumpolar Health, 3d, Yellowknife, Northwest Territories, Can., 1974.

Circumpolar health.

Includes Index.

1. Arctic Medicine - Congresses. 2. Eskimos - Health and

hygiene - Congresses. 3. Lapps - Health and hygiene - Congresses. 4. Indians of North America - Health and hygiene - Congresses. I. Shephard, Roy J. II. Itoh, Shinji, 1912 - III. Canada. Medical Services Branch, Northwest Territories Region. IV. Title. [DNLM: 1. Cold climate - Congresses. W3 IN916VE 1974C / QT160 161 1974c] RC955.2.157 $1974 \quad 613.1 ' 11 \quad 76-2608$

ISBN 0-8020-3333-4

ISBN 978-1-4875-8094-0 (paper) 